Article

\title{
Development of a Quarantine Postharvest Treatment against Guatemalan Potato Moth (Tecia solanivora Povolny)
}

\author{
María Gloria Lobo ${ }^{1, *(\mathbb{D})}$, Cristina González-García ${ }^{2}$, Raimundo Cabrera ${ }^{3}$ and Domingo Ríos 4 \\ 1 Producción Vegetal en Zonas Tropicales y Subtropicales, Instituto Canario de Investigaciones Agrarias, \\ 38270 San Cristóbal de La Laguna, Tenerife, Spain \\ 2 Gestión del Medio Rural de Canarias, SAU, 38110 Santa Cruz de Tenerife, Tenerife, Spain; \\ crisgonzalez@gmrcanarias.com \\ 3 Botánica, Ecología y Fisiología Vegetal, Universidad de La Laguna, 38206 San Cristóbal de La Laguna, \\ Tenerife, Spain; rcabrera@ull.es \\ 4 Cabildo Insular de Tenerife, 38007 Santa Cruz de Tenerife, Tenerife, Spain; domingor@tenerife.es \\ * Correspondence: globo@icia.es
}

Citation: Lobo, M.G.; GonzálezGarcía, C.; Cabrera, R.; Ríos, D. Development of a Quarantine Postharvest Treatment against Guatemalan Potato Moth (Tecia solanivora Povolny). Agriculture 2021, 11, 801. https://doi.org/10.3390/ agriculture11080801

Academic Editor: Roy Kennedy

Received: 20 July 2021

Accepted: 15 August 2021

Published: 23 August 2021

Publisher's Note: MDPI stays neutral with regard to jurisdictional claims in published maps and institutional affiliations.

Copyright: (c) 2021 by the authors. Licensee MDPI, Basel, Switzerland. This article is an open access article distributed under the terms and conditions of the Creative Commons Attribution (CC BY) license (https:/ / creativecommons.org/licenses/by/ $4.0 /)$.

\begin{abstract}
Tecia solanivora is a quarantine organism regarded as one of the insect pests causing major economic losses during potato cultivation and storage in Central America. The potatoes trade between countries, the interest in introducing new potato varieties, the great adaptability of the insect to different agro-ecological conditions, and the globalization world are serious risks in other potato growing countries. This pest was first recorded in Europe in the Canary Islands, Spain, in 1999, later in Galicia (2015) and then in Asturias (2016). Unfortunately, there are no effective chemical treatments for field control, and their integrated management has variable efficacy. Therefore, the implementation of a postharvest treatment to eradicate the insect, at any stage, during storage and marketing of potato becomes essential to achieve a product free of the insect that prevents its dissemination while maintaining the quality during its commercialization. This article presents the development of a new postharvest treatment of potatoes to eliminate all developmental stages of the Guatemalan moth by the application of a control atmosphere enriched in carbon dioxide. Infested potatoes were exposed to different control atmospheres combination $\left(10,20,30,40\right.$, or $50 \% \mathrm{CO}_{2}$, $20 \% \mathrm{O}_{2}$, and rest of $\mathrm{N}_{2}$ ). These treatments were applied for 4,7 , and 10 days at $18 \pm 2{ }^{\circ} \mathrm{C}$. The 10 days duration treatment $\left(30 \pm 2 \% \mathrm{CO}_{2}, 20 \pm 2 \% \mathrm{O}_{2}\right.$ and $50 \pm 2 \% \mathrm{~N}_{2}$ ) killed the insect in the semi and commercial trials performed without affecting potatoes quality and postharvest life, giving the possibility of its consideration as a quarantine postharvest treatment against $T$. solanivora.
\end{abstract}

Keywords: phytosanitary; insect; control atmosphere; potato quality

\section{Introduction}

Tecia solanivora Povolny, commonly known as Guatemalan moth, was first reported in 1956 in Guatemala. This Lepidopteran insect of the Gelechiidae family severely damage potato crops (Solanum sp.), producing big losses in the field and during commercialization [1]. Although this insect has reduced mobility, it has invaded several countries in Central and South America reaching the Canary Islands in Spain (Europe) in 1999 as described by the European and Mediterranean Plant Protection Organization (EPPO) in the report RS 2001/129 [2] and by Villanueva and Saldamando [3]. In 2015, the pest reached the Spanish Peninsula (Galicia) (EPPO 2015/202; EPPO 2016/131) [4,5] and then Asturias in 2016 [6] (EPPO 2017/080) despite the existence of a European Community Order in which this organism is included in the Annex II, PART A of "harmful organisms whose introduction and propagation should be prohibited in all member states, if present in certain plants or plant products" as modified by ORDEN ARM/1671/2009 of 16th of June referred to RD 58/2005 of 21st January. 
Therefore, T. solanivora is a quarantine insect in the European Union since 2006 [7], and its presence prohibits the potatoes exportation to any member of the European Union and other countries in which the pest is not present.

This pest, of rapid dissemination, mainly due to potato trade (seeds and tubers), can cause losses up to 70-80\% [3]. It has been classified as one of the most harmful pests because it affects tubers in the field and in the warehouse in countries where potato is an important family staple and production is very intensive.

Potato is the only host identified so far for T. solanivora larvae [2,8]. Tuber damage is similar but greater to that caused by other tuber moths such as Phthorimaea operculella Zeller [1]. In potato fields, the insect attack occurs from tuberization until harvest. Adult females enter soil crevices to oviposit close to potato tubers, and their larvae feeding on tubers are largely protected from insecticide sprays [9] and from predators. After egg hatching, larvae penetrate in the potato skin and bore irregular galleries that run into the tubers containing food residues, frass, and larval exuviate. As larvae develop inside the tubers, feces become visible around the entry hole indicating infestation. Circular exit holes of 2-3 mm are visible when the larvae leave tubers to pupate in soil, near the plant surface. Eggs laid on the potatoes due to their sticky surface, or the first instar larvae, get camouflaged by soil particles and cannot be seen when the operator tries to discard the infested tubers entering, consequently, in the warehouses and marketing chain.

"Papas Antiguas de Canarias" (Ancient potatoes), are most likely selections, hybrids, or variants of the early tubers brought to Canary Islands from America where are cultivated since the 16th century and contributes to its unique biodiversity in the world [10,11]. Only 29 varieties produced in the Canary Islands and one, "Patata di Bolonia" from Italy, are part of the prestigious European Seal Protected Designation of Origin (PDO). These potatoes are grown on so-called terraces, areas of flat land arranged in stepped fashion along the mountainsides. In warmer areas where the slopes are less steep, the crop is also grown in gavias or bebederos (small plots of land where rainwater accumulates). In this case, the crops are covered with jable, or volcanic sand, to prevent water evaporating, contributing to a landscape of incalculable environmental value in the production areas [12].

According to several authors [1,3] the Guatemalan potato moth is considered one of the most harmful insect pests of potato crops in Central America, Venezuela, Colombia, Ecuador, and Spain (EU) producing 50-70\% economic losses. Lara et al. [13] pointed out the foreseeable consequences in the Canary Islands from an economic perspective, the loss of traditional farming methods that are a source of income and employment in rural area, and from an environmental perspective, the loss of agro-biodiversity through the disappearance of varieties that are unique in the world, the abandonment of farmland, and a probable change in land use to other activities. Therefore, social, cultural, and political variables surround the pest infection.

Nowadays, no treatments are able to eradicate the pest in the field. The use of chemical insecticides [14], plant products (extracts or essential oils) [14] cultural practices (planting deeper, hilling and moistening the ground, crop rotation, etc.) [15], integrated management $[3,16,17]$, pheromones [9], insect resistant potatoes [16,17], etc., try to maintain the pest at levels that do not lead to great economic losses. Moreover, controlling this pest has proven to be even difficult when potatoes are harvested due to the healthy appearance during the first stages of infestation; therefore, infested potatoes usually evade any kind of phytosanitary visual control.

Phytosanitary treatments are often required for imported commodities to prevent the introduction of quarantine pests. Such treatments need to be appropriate for a specific commodity, effective against the quarantine pests of that commodity, and not dangerous for the personnel who apply it and must not leave any residue that could be dangerous to the consumer and be feasible in terms of applicability and costs.

With the concerns about health hazards of chemical pesticides and their resulting environmental pollution, there is increasing interest in developing postharvest alternatives, nonchemical process protocols to control insect pests while the product retains its quality. 
These include, among others, conventional hot air or water heating, cooling, controlled atmosphere, irradiation, and dielectric heating (radio frequency (RF) and microwave (MW)) [18-22].

Control atmospheres enriched with carbon dioxide $\left(\mathrm{CO}_{2}\right)$ have been developed to control pests that affect long-term storage foods (grains, fruits, seeds, or dry fruits). Elevated $\mathrm{CO}_{2}$ levels cause spiracles to open resulting in insect death from water loss. At $\mathrm{CO}_{2}$ concentration above $10 \%$, spiracles remain permanently open producing toxic effects on the nervous system, through the tracheae and not the hemolymph. In some cases, $\mathrm{CO}_{2}$ can acidify the hemolymph leading to membrane failure in some tissues [23]. Ruidavets et al. [24] found that the use of $\mathrm{CO}_{2}$ at high pressure is one of the most rapid options for arthropod pest control among current commercial treatments. Nevertheless, although high-pressure carbon dioxide treatments (10-37 bar) can significantly shortened exposure times to hours, the designed metal chambers that stand the high pressures need a high initial capital investment, being only practical for high-value products such as spices, nuts, medicinal herbs, and other special commodities [25].

Due to the economic losses that a pest insect causes and the phytosanitary barriers imposed by each country to import foodstuff, it is essential to establish an effective treatment against each quarantine insect for a given crop in its marketing conditions.

The aim of this study was to develop a quarantine postharvest potato treatment using enriched carbon dioxide control atmospheres against $T$. solanivora keeping the organoleptic characteristics and the shelf life of the tubers and, additionally, not affecting the sprout capability of the seeds.

\section{Materials and Methods}

\subsection{Insect Rearing}

Infested potatoes were harvested from different crops in Tenerife (Canary Islands, Spain). The potatoes were placed, in a constant climate chamber (BINDER, Tuttlingen, Germany) ( $\left.20 \pm 2{ }^{\circ} \mathrm{C}, 70 \pm 2 \% \mathrm{RH}, 16: 8 \mathrm{~h} \mathrm{light/dark}\right)$, in boxes with a cloth over them to facilitate the larvae to pupae. Pupae $(n=20)$ were then selected and held in cylindrical containers $(15 \mathrm{~cm}$ diameter $\times 20 \mathrm{~cm}$ height). Once the adults emerged those identified as T. solanivora were kept in cylindrical containers impregnated with a $10 \%(v / v)$ solution of honey in tap water for mating. Filter paper at the base of the containers served as the oviposition substrate. Small pieces of paper with the moth eggs were placed over 6 potatoes and kept in $22 \times 15 \times 9 \mathrm{~cm}$ (length by width by height) semi-transparent polyethylene boxes with leak-proof locking lids and a $10 \mathrm{~cm}$ diameter mesh window. Then, 15 days later, a cloth was deposited over each potato closing the insect cycle life.

The rearing was performed exponentially to obtain enough insects in the different life stages (eggs, larvae, pupae, and adults) to carry out the tests.

\subsection{Insect Mortality Curves}

To determine the mortality curves of the Guatemalan moth in its different stages, different control atmospheres enriched with carbon dioxide were evaluated $\left(0,10,20,30,40\right.$ or $50 \% \mathrm{CO}_{2}, 20 \% \mathrm{O}_{2}$, and the rest $\left.\mathrm{N}_{2}\right)$. These treatments were applied for 4, 7, and 10 days in airtight chambers of a capacity of nearly $0.20 \mathrm{~m}^{3}$ ( $80 \mathrm{~cm}$ length $\times 60 \mathrm{~cm}$ width $\times 40 \mathrm{~cm}$ height). Ten days before applying the treatments, 3 containers with 15 non-infested potatoes each were inoculated with 7 eggs (315 eggs in total for each treatment). For every controlled atmosphere treatment, 3 cylindrical containers containing 30 pupae each ( $n=90$ for each treatment) and another 3 with 10 adults each $(n=30$, for each treatment) were prepared for the assay. Finally, 5 plate dishes with 4 little pieces of paper with 7 eggs each $(n=140$, for each treatment) were set.

Each treatment was performed in triplicate, using three airtight chambers (18 in total). The control treatment was air $\left(0 \% \mathrm{CO}_{2}, 20 \% \mathrm{O}_{2}\right.$, and $\left.80 \% \mathrm{~N}_{2}\right)$. Once the chambers were closed, the controlled atmosphere was introduced as explained in Section 2.3.

Survival of insects to the adult stage was evaluated for 8 weeks. 


\subsection{Gas Introduction}

Gases were purchased locally from "AL Airliquide S.A. (Tenerife, Canary Islands, Spain). After accommodating the containers with the potatoes inoculated with eggs or larvae, the adults, and the pupae in the hermetic chambers, a mixture of $\mathrm{CO}_{2}, \mathrm{O}_{2}$, and $\mathrm{N}_{2}$ made with a (Witt-Gasetechnik, KM 100-3 model, Witten, Germany) was introduced through an inlet valve, while the air came out from the outlet valve of the chamber to avoid creating pressure. The gas concentration was measured from the outlet valve with a PBI Dansensor CheckMate $9900\left(\mathrm{O}_{2} / \mathrm{CO}_{2}\right)$ head space analyser (PBI- Dan sensor, Denmark) previously stabilized at ambient temperature and calibrated. Once the sensor indicated that the required concentration was achieved, the injector gas tube was removed, and both valves were tightly closed. Every $6 \mathrm{~h}$, the atmosphere was analysed and restored in case the gases were not in the proper concentration (concentration tested $\pm 2 \%$ ). Chambers were provided with a fan to circulate the controlled atmosphere to avoid gas stratification. In the control treatment, ambient air was introduced into the containers as already described for $\mathrm{CO}_{2}$ introduction. After the gas introduction, chambers were maintained at $20 \pm 2{ }^{\circ} \mathrm{C}$, $70 \pm 2 \%$ RH.

\subsection{Effect of Chosen Treatments on the Postharvest Behaviour, Sensory Quality, and Germination Capacity of the Tubers}

The most effective treatments that resulted from the previous assay were evaluated on potatoes of two varieties "Negra Yema de Huevo" (Solanum chaucha, "Papa Antigua de Canarias", usually consumed salt boiled) and "Druid" (S. tuberosum, Irish potato, suitable for crisping and French fries) not only in terms of insect survival but also in the postharvest behaviour, sensory quality, and germination capacity and productivity in the field.

\subsubsection{Treatment Effectivity on Insects}

Ten days before applying the treatments, 5 containers with 15 non-infested potatoes each were inoculated with 7 eggs $(n=525)$ in order to have the potatoes with the larvae. Moreover, for every controlled atmosphere treatment, 3 cylindrical vases containing 20 pupae each ( $n=60$ for each treatment) and another 3 with 10 adults each ( $n=30$, for each treatment) were prepared for the assay. Finally, 3 plate dishes with 4 little pieces of paper with 7 eggs each $(n=84$, for each treatment) were set. The same number of insects were used in the control treatment $\left(0 \% \mathrm{CO}_{2}, 20 \% \mathrm{O}_{2}\right.$, and $\left.80 \% \mathrm{~N}_{2}\right)$.

The gases were injected in the chambers as explained above, and once the controlled atmosphere was achieved, it was maintained for the number of days indicated by the results of the previous assay.

The viability and survival of the insect in its different life stages were evaluated for 8 weeks.

\subsubsection{Postharvest Behaviour}

Two boxes containing $20 \mathrm{~kg}$ of potatoes of each variety were introduced in the airtight chambers with the controlled atmospheres. This assay was made in triplicate. The boxes were stored at $9 \pm 2{ }^{\circ} \mathrm{C}$ and $60 \% \mathrm{HR}$ in darkness.

Quality analysis for controlling pulp and peel colour, hardness, and \% dry matter was assessed at the end of each treatment and for 3 months once every month, in 10 potatoes. It should be noted that non-inhibitors for germination were applied.

A CIELAB colorimetry system was used to define the peel and pulp colour, using a Konica Minolta CR-300 Chroma Meter (Jersey, NJ, USA), which recorded the spectrum of reflected light and converted it into a set of colour coordinates $\left(\mathrm{L}^{*}, \mathrm{a}^{*}\right.$ and $\mathrm{b}^{*}$ values). A standard white plate was used to standardize the instrument [26]. Instrumental colour was expressed as chroma $\left[\left(a^{* 2}+b^{* 2}\right)^{* 0.5}\right]$ and hue angle [arctan $\left.\left(b^{*} / a^{*}\right) \times 180 / 3.14\right]$ [27]. Colour measurements were obtained in triplicate from peel and from pulp of each analysed potato. 
The hardness measurements were carried out in a rapid non-destructive way using a Durofel (CTIFL Copa Technologie, Saint Etienne du Gres, France) dynamometer with a bolt of $3 \mathrm{~mm}$ diameter.

Dry matter content was determined by weight loss of a 5-10 g fresh weight (FW) pulp sample until constant weight in a forced air oven $\left(50 \pm 2{ }^{\circ} \mathrm{C}\right)$.

\subsubsection{Organoleptic Analysis}

To determine the effect of the treatment on organoleptic quality, the external appearance of the tubers was evaluated by comparison tests A/no A, in accordance with Standard UNE 87016-86.

In addition, a study of olfactory-gustatory differences between the batches of treated potatoes and the untreated (control) was conducted by triangular tests in accordance with Standard UNE-EN ISO 4120, with the two batches treated against the control. The samples were presented to a trained panel $(n=10)$ in plastic petri dishes and under red light, to mitigate the effect of the appearance on the sensory evaluation, identified with random three-digit codes and in the proportions and order proposed by the UNE 87006 standard. The trained panel was told to give necessarily an answer (forced judgment). Organoleptic analysis was performed at the end of the treatment and one month after cold storage.

\subsubsection{Germination Capacity and Productivity}

The treated potatoes of each variety ("Negra Yema de Huevo" and "Druid") were planted in pots $(n=30)$ and at random blocks and both the number of potatoes produced and each potato weight were evaluated.

\subsection{Semi-Commercial Scale Trials}

A European pallet with $3 \mathrm{~kg}$ boxes of "Papas Antiguas de Canarias" potatoes (128 boxes in total arranged in 8 rows of 16 boxes each; $384 \mathrm{~kg}$ in total) was treated with the proposed quarantine-controlled atmosphere treatment in a controlled atmosphere chamber $\left(2.40 \mathrm{~m}\right.$ length $\times 2.10 \mathrm{~m}$ width $\times 2.33 \mathrm{~m}$ height; $\left.11.75 \mathrm{~m}^{3}\right)$. In rows $1,3,4,5$, and 7 (Figure 1), 1 box was filled with potato classified as infested (not healthy) and another as healthy by the farmer presuming that the insect was either present or not, respectively. Another box was filled with potatoes infested in the laboratory with larva (20 potatoes with 5 larvae each, $n=100$ ) and separated with paper from the 20 potatoes infested with 5 eggs each ( $n=100$ eggs). The last box was prepared with 2 cylindrical vessels, one containing 20 adults and the other 20 pupae. The 4 boxes were located in the inner part of the pallet in order to provoke the most difficult conditions for the treatment to reach the insects.
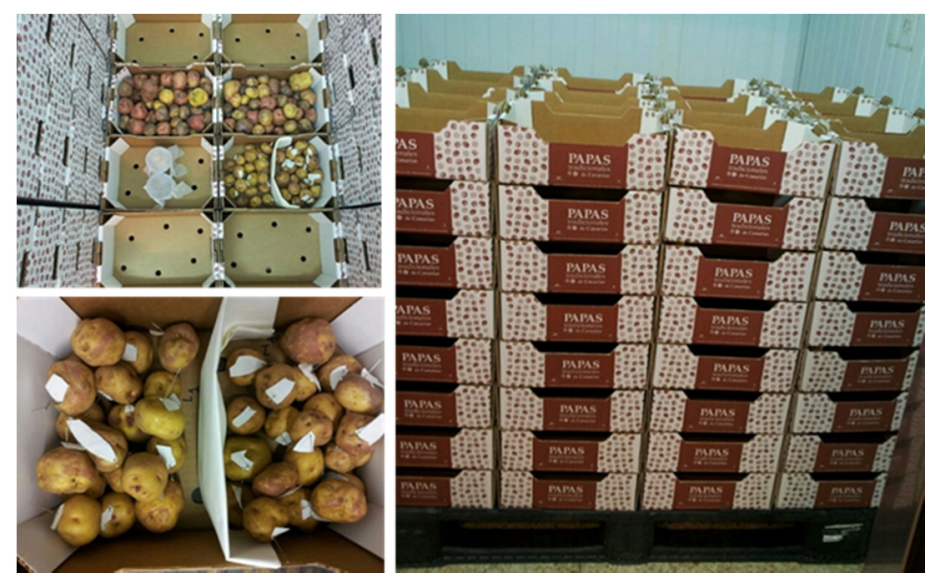

Figure 1. Semi-commercial trial. Pallet preparation using inoculated potatoes with eggs and larvae, pupae and adults in cylindrical vases, and one box of healthy and another of infested potatoes classified by the farmer. Photos: M.G. Lobo. 
The atmosphere was injected, and the concentration controlled as explained before. This trial was conducted twice at $17 \pm 2{ }^{\circ} \mathrm{C}$.

\subsection{Commercial Scale Trials}

A commercial controlled atmosphere chamber $(5.00 \mathrm{~m}$ length $\times 3.50 \mathrm{~m}$ width $\times 2.20 \mathrm{~m}$ height; $38.5 \mathrm{~m}^{3}$ ) was built in GMR Canarias (Ingeniería y Arquitectura Techne, S.L., Santa Cruz de Tenerife, Spain) facilities. This chamber is provided with temperature, carbon dioxide, and oxygen concentration probes, and the injection and adjustment of the gases are automatically controlled. Finally, a display indicates and registers the conditions inside the chamber during the whole treatment. The capacity is for 12 European pallets $(0.80 \mathrm{~m} \times 1.00 \mathrm{~m})$. Two trials were performed at $17 \pm 2{ }^{\circ} \mathrm{C}$ :

In the first one, 12 European pallets were prepared using 16 boxes at the base and 8 rows high (128 boxes of approximately $3 \mathrm{~kg}$ each; $4608 \mathrm{~kg}$ of "Papas Antiguas de Canarias" potatoes). In the central part of the 4 th row of each of the 12 pallets, 4 boxes were prepared as in Figure 2:

(a) Box with 15 potatoes inoculated with 15 eggs each $(15$ potatoes $\times 15$ eggs $\times 12$ pallets: 2700 eggs in total) and a cylindrical vase with 15 adults (15 adults $\times 12$ pallets; 180 adults in total). The rest of the box was completed with healthy potatoes.

(b) Box with 15 potatoes inoculated with 15 larvae each (15 potatoes $\times 15$ larvae $\times$ 12 pallets: 2700 larvae in total) and a cylindrical vase with 15 pupae (15 pupae $\times$ 12 pallets; 180 pupae). The rest of the box was completed with healthy potatoes.

(c) Box classified as healthy, without the presence of the insect after a visual observation by the farmer ( 1 box $\times 12$ pallets; 12 healthy boxes).

(d) Box classified as infested (not healthy), with the presence of the insect after visual observation by the farmer ( 1 box $\times 12$ pallets; 12 infested boxes).
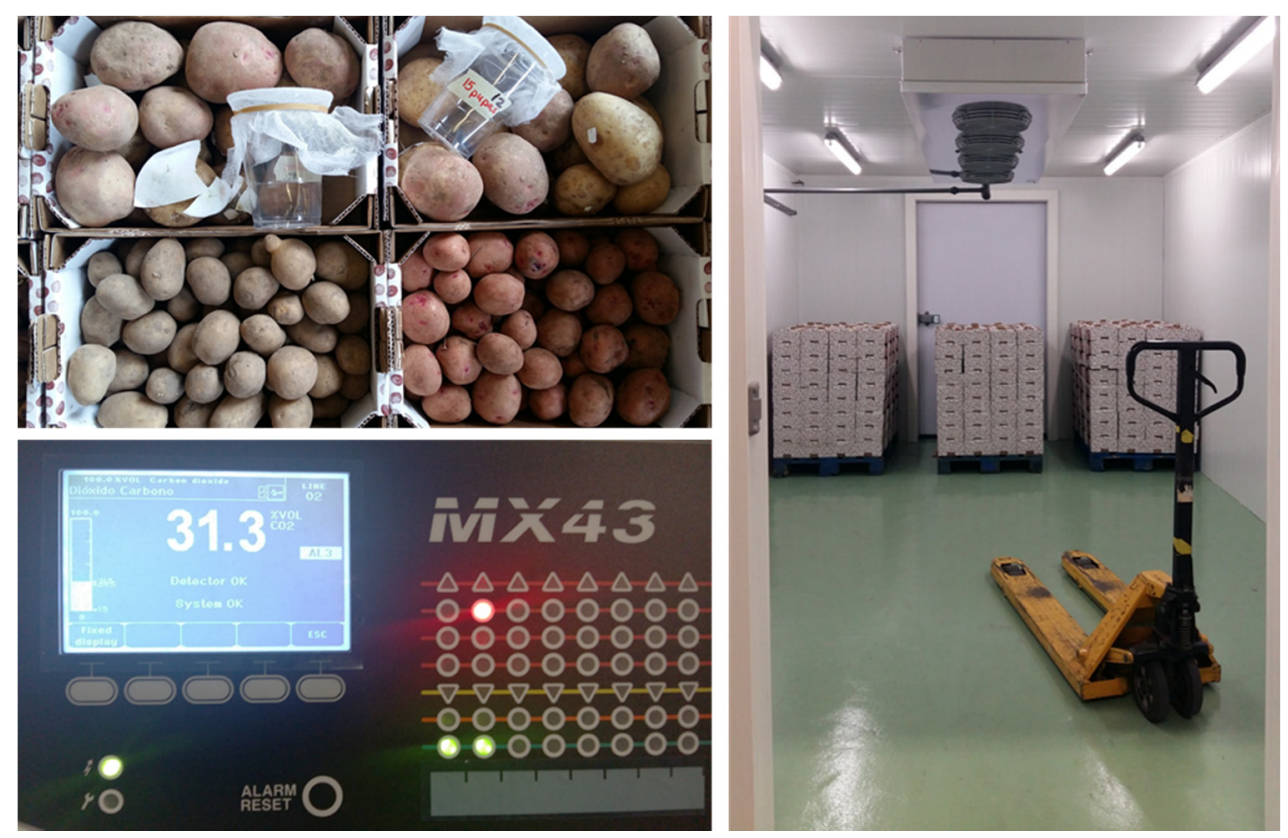

Figure 2. Commercial trial. Pallet preparation using inoculated potatoes with eggs and larvae, pupae, and adults in cylindrical vases, and one box of healthy and another of infested potatoes classified by the farmer. Photos: M.G. Lobo.

For the control 2 boxes containing 15 potatoes inoculated with 15 eggs each (15 potatoes $\times 15$ eggs $\times 2$ boxes; 450 eggs in total), 2 boxes containing 15 potatoes inoculated with 15 larvae each (15 potatoes $\times 15$ larvae $\times 2$ boxes; 450 larvae in total), 3 cylindrical vases with 15 pupae each (45 pupae in total), and 3 cylindrical vases with 15 adults each (45 adults in total) were prepared and stored at $20 \pm 2{ }^{\circ} \mathrm{C}$. 
After completing the pallets' boxes with healthy potatoes, the chamber was filled and closed to assess the programmed treatment. The controlled atmosphere had to be maintained, so when temperature or oxygen or carbon dioxide concentrations increase or decrease, $\pm 2 \%$ was automatically restored.

In the second commercial trail, the assay was conducted using 12 European pallets prepared using 8 boxes at the base and 11 rows high ( 88 boxes of approximately $7.5 \mathrm{~kg}$ each; $7920 \mathrm{~kg}$ of potatoes). In the central part of the 6 th row of each of the 12 pallets, 4 boxes were prepared as follows:

(a) Box with 10 potatoes inoculated with 15 eggs each (10 potatoes $\times 15$ eggs $\times 12$ pallets: 1800 eggs in total), and a cylindrical vase with 15 adults ( 15 adults $\times 12$ pallets; 180 adults in total). The rest of the box was completed with healthy potatoes.

(b) Box with 10 potatoes inoculated with 15 larvae each (10 potatoes $\times 15$ larvae $\times$ 12 pallets: 1800 larvae in total), and a cylindrical vase with 15 pupae (15 pupae $\times 12$ pallets; 180 pupae in total). The rest of the box was completed with healthy potatoes.

(c) Box classified as healthy, without the presence of the insect after a visual observation by the farmer ( 1 box $\times 12$ pallets; 12 healthy boxes).

(d) Box classified as infested (not healthy), with the presence of the insect after visual observation by the farmer ( 1 box $\times 12$ pallets; 12 non-healthy boxes).

For the control 3 boxes containing 10 potatoes inoculated with 15 eggs each (10 potatoes $\times 15$ eggs $\times 3$ replicates; 450 eggs in total), 3 boxes containing 10 potatoes inoculated with 15 larvae each (10 potatoes $\times 15$ larvae $\times 3$ replicates; 450 larvae in total), 3 cylindrical vases with 15 pupae each (45 pupae in total), and 3 cylindrical vases with 15 adults each (45 adults in total) were prepared and stored at $20 \pm 2{ }^{\circ} \mathrm{C}$.

The controlled atmosphere chamber was filled with the pallets and the treatment applied as explained in the previous trial.

The viability and survival of the insect in its different stages was evaluated for 8 weeks in both trials.

\subsection{Statistical Analysis}

The statistical analysis of the data was carried out with the statistical program STATGRAPHICS 5.1. The analysis of variance (ANOVA) was used, and the Fisher's LeastSignificant Differences (LSD) Test at the 95\% confidence level was applied to estimate the statistically significant differences between the evaluated treatments in normal distribution, using Kruskal-Wallis when the distribution was not normal.

Mortality data obtained from the treatments were corrected by using Abbott's formula [28] when the insects number in the control and those in the treatment were the same (uniform population) and [29] when the population was not uniform. Mortality data were subjected to Arcsin transformation and then were analysed using one-way analysis of variance (ANOVA). The means were analysed using the LSD method at 5\% level. KruskalWallis test and comparison tests were performed at $p \leq 0.05$ when needed (not normal distribution, hedonic scales, etc.)

\section{Results}

Insect rearing was achieved using potatoes and not an artificial diet.

\subsection{Insect Mortality Curves}

Figure 3 shows the insect mortality curves for eggs, larvae, pupae, and adults, depending on the concentration of the controlled atmosphere enriched in carbon dioxide and the application time.

The exposition of the insects to a $10 \% \mathrm{CO}_{2}$ control atmosphere did not kill them, being capable of completing their biological cycle, except for the adults. Although the increase of treatment days caused greater mortality, the insects kept the ability to complete their life cycle, and those that reached adulthood laid eggs. 
The $20 \% \mathrm{CO}_{2}$ enriched atmosphere applied for 4 days lead the eggs to hatch but the larvae were not able to pupate. On the other hand, the treated pupae developed in unfertile adults. The same effect was observed when they were treated for 7 and 10 days, aggravated by a smaller population of the insect because the treatments were more effective than when it was applied for 4 days.

Only a few eggs were able to hatch when $30 \% \mathrm{CO}_{2}$ was used in the 4-day treatment. Moreover, the few emerging larvae died rapidly, while the adults that emerged from the treated pupae were not able to mate and complete their biological cycle. When the treatment was extended to 7 or 10 days, no insects in their different stages were viable.

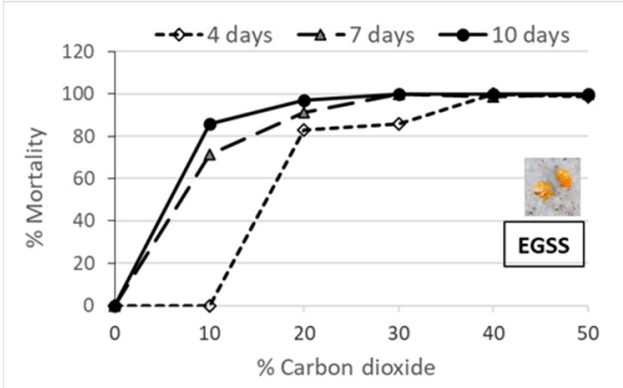

(a)

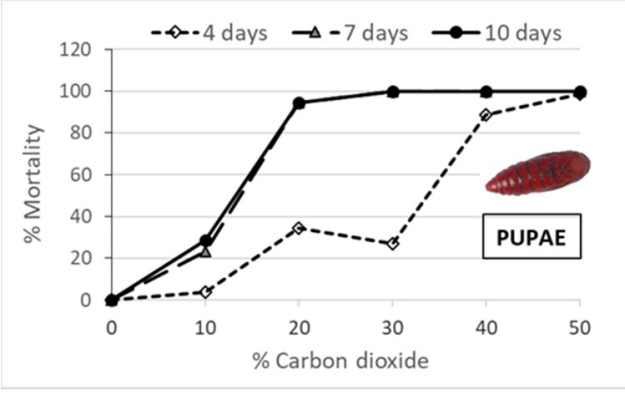

(c)

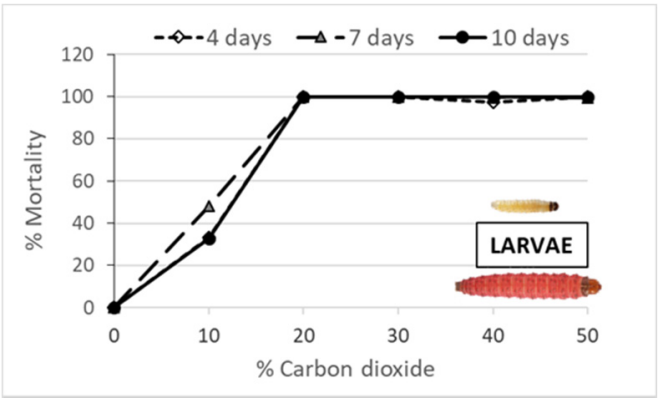

(b)

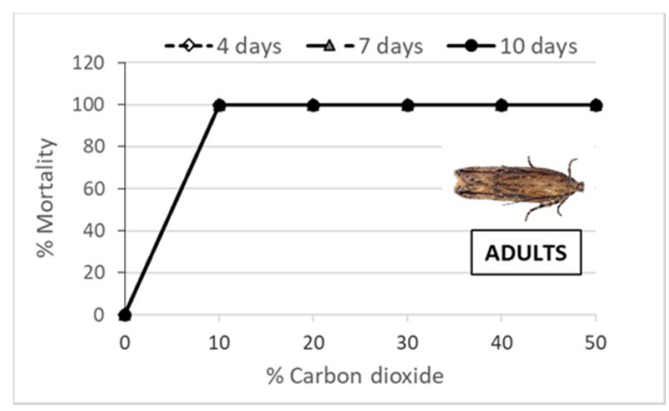

(d)

Figure 3. Insect mortality curves when exposed (a) eggs, (b) larvae, (c) pupae, or (d) adults were exposed to an enriched atmosphere in $0,10,20,30,40$, and 50\% carbon dioxide; $20 \%$ oxygen; and the rest nitrogen for 4,7 , or 10 days. Photos: F. Correa.

\subsection{Effect of Chosen Treatments on the Postharvest Behaviour, Sensory Quality, and Germination Capacity of the Tubers}

In this assay, two controlled atmospheres, applied for 10 days, were performed: $20 \% \mathrm{CO}_{2}, 20 \% \mathrm{O}_{2}$, and $60 \% \mathrm{~N}_{2}$; and $30 \% \mathrm{CO}_{2}, 20 \% \mathrm{O}_{2}$, and $50 \% \mathrm{~N}_{2}$ using potatoes from two varieties ("Negra Yema de Huevo" and "Druid").

\subsubsection{Treatment Effectivity on Insect Survival}

The controlled atmosphere $30 \% \mathrm{CO}_{2}, 20 \% \mathrm{O}_{2}$, and $50 \% \mathrm{~N}_{2}$ applied for 10 days achieved $100 \%$ mortality of the insect in all the stages ( 84 eggs, 525 larvae, 60 pupae, and 30 adults) being the one proposed as a quarantine postharvest treatment for Tecia solanivora (Table 1). The one with $20 \% \mathrm{CO}_{2}$ allowed the development of some eggs and pupae, and therefore, although it was not statistically different to the $30 \% \mathrm{CO}_{2}$ treatment, cannot be proposed as a quarantine treatment.

The results conducted at a small scale in this trial suggested that the treatment that could be used as a quarantine postharvest treatment needs a concentration of at least $30 \%$ $\mathrm{CO}_{2}, 20 \% \mathrm{O}_{2}$, and $50 \% \mathrm{~N}_{2}$ for 10 days. 
Table 1. Mortality and percentage of efficacy when Tecia solanivora in different life stages was exposed to 20 or $30 \%$ carbon dioxide-controlled atmospheres at $20^{\circ} \mathrm{C}$.

\begin{tabular}{|c|c|c|c|c|c|}
\hline & \multicolumn{3}{|c|}{ Mortality (\%) } & \multicolumn{2}{|c|}{ Efficacy Percentage (\%) } \\
\hline & $20 \% \mathrm{CO}_{2}$ & $30 \% \mathrm{CO}_{2}$ & Control & $20 \% \mathrm{CO}_{2}$ & $30 \% \mathrm{CO}_{2}$ \\
\hline Eggs $(n=84)$ & $98.8 \pm 2.06^{*}, \mathrm{a}$ & $100.00 \pm 0.00 \mathrm{a}$ & $58.33 \pm 16.10 b$ & $95.24 \pm 8.25 \mathrm{a}$ & $100.00 \pm 0.00 \mathrm{a}$ \\
\hline Larvae $(n=525)$ & $100.0 \pm 0.00 \mathrm{a}$ & $100.00 \pm 0.00 \mathrm{a}$ & $44.95 \pm 3.71 \mathrm{~b}$ & $100.00 \pm 0.00 \mathrm{a}$ & $100.00 \pm 0.00 \mathrm{a}$ \\
\hline Pupae $(n=60)$ & $95.0 \pm 5.00 \mathrm{a}$ & $100.00 \pm 0.00 \mathrm{a}$ & $13.33 \pm 3.71 \mathrm{~b}$ & $94.12 \pm 5.88 \mathrm{a}$ & $100.00 \pm 0.00 \mathrm{a}$ \\
\hline Adults $(n=30)$ & $100.0 \pm 0.00 \mathrm{a}$ & $100.00 \pm 0.00 \mathrm{a}$ & $3.33 \pm 5.77 b$ & $100.00 \pm 0.00 \mathrm{a}$ & $100.00 \pm 0.00 \mathrm{a}$ \\
\hline
\end{tabular}

${ }^{*}$ Mean \pm SD followed by different letter in the same line are significantly different $(p \leq 0.05)$ according to ANOVA test followed by post hoc LSD test.

\subsubsection{Postharvest Behaviour}

A total of $40 \mathrm{~kg}$ of two potatoes varieties ("Negra Yema de Huevo" and "Druid") were treated with 20 or $30 \% \mathrm{CO}_{2}, 20 \% \mathrm{O}_{2}$, and the rest $\mathrm{N}_{2}$ for 10 days. Peel and pulp colour, hardness, and \% of dry matter were analysed after treatment and 1,2, or 3 months of storage (Table 2).

Table 2. Effect of 10-day 20 or 30\% carbon dioxide-controlled atmosphere treatments at $20{ }^{\circ} \mathrm{C}$ on potato ("Negra Yema de Huevo" and "Druid") postharvest behaviour at $0,1,2$, or 3 storage months.

\begin{tabular}{|c|c|c|c|c|c|c|c|c|c|}
\hline \multicolumn{10}{|c|}{ “Negra Yema de Huevo" Variety } \\
\hline & & $\begin{array}{c}\mathbf{L}^{*} \\
\text { Peel }\end{array}$ & $\begin{array}{l}\text { Hue } \\
\text { Peel }\end{array}$ & $\begin{array}{c}\text { Chroma } \\
\text { Peel }\end{array}$ & $\begin{array}{l}\text { Hardness } \\
{ }^{\circ} \text { Durofel }\end{array}$ & $\begin{array}{c}\mathbf{L}^{*} \\
\text { Pulp }\end{array}$ & $\begin{array}{l}\text { Hue } \\
\text { Pulp }\end{array}$ & $\begin{array}{c}\text { Chroma } \\
\text { Pulp }\end{array}$ & $\begin{array}{c}\text { Dry Matter } \\
\%\end{array}$ \\
\hline \multirow{3}{*}{$\begin{array}{c}\text { After } \\
\text { treated }\end{array}$} & Control & $48.2 *, \mathrm{a}$ & $54.5 \mathrm{a}$ & $11.9 \mathrm{a}$ & $87.7 \mathrm{a}$ & $72.7 \mathrm{a}$ & $98.1 \mathrm{a}$ & $44.8 \mathrm{a}$ & $24.7 \mathrm{a}$ \\
\hline & $20 \% \mathrm{CO}_{2}$ & $48.9 \mathrm{a}$ & $64.5 \mathrm{a}$ & $13.9 \mathrm{a}$ & $91.0 \mathrm{a}$ & $70.0 \mathrm{a}$ & $97.8 \mathrm{a}$ & $44.3 \mathrm{a}$ & $25.3 \mathrm{a}$ \\
\hline & $30 \% \mathrm{CO}_{2}$ & 48.7 a & $58.2 \mathrm{a}$ & $12.2 \mathrm{a}$ & $89.4 \mathrm{a}$ & $72.0 \mathrm{a}$ & $98.7 \mathrm{a}$ & $42.7 \mathrm{a}$ & $25.2 \mathrm{a}$ \\
\hline \multirow{3}{*}{1 month } & Control & $41.2 \mathrm{a}$ & $53.6 \mathrm{a}$ & $13.8 \mathrm{a}$ & $85.8 \mathrm{a}$ & $72.9 \mathrm{a}$ & $99.2 \mathrm{a}$ & $44.2 \mathrm{a}$ & $21.7 \mathrm{a}$ \\
\hline & $20 \% \mathrm{CO}_{2}$ & $42.0 \mathrm{a}$ & $65.4 \mathrm{a}$ & $17.0 \mathrm{a}$ & $86.2 \mathrm{a}$ & $74.2 \mathrm{a}$ & $99.0 \mathrm{a}$ & $45.0 \mathrm{a}$ & $21.0 \mathrm{a}$ \\
\hline & $30 \% \mathrm{CO}_{2}$ & $43.0 \mathrm{a}$ & $63.8 \mathrm{a}$ & $14.1 \mathrm{a}$ & $85.2 \mathrm{a}$ & $74.1 \mathrm{a}$ & $99.6 \mathrm{a}$ & $45.2 \mathrm{a}$ & $20.6 \mathrm{a}$ \\
\hline \multirow{3}{*}{2 months } & Control & $40.5 \mathrm{a}$ & $62.2 \mathrm{a}$ & $13.3 \mathrm{a}$ & $77.3 \mathrm{~b}$ & $74.7 \mathrm{a}$ & $99.3 \mathrm{a}$ & $46.8 \mathrm{a}$ & $24.8 \mathrm{a}$ \\
\hline & $20 \% \mathrm{CO}_{2}$ & $39.7 \mathrm{a}$ & $51.9 \mathrm{a}$ & $13.0 \mathrm{a}$ & $78.8 \mathrm{~b}$ & $74.9 \mathrm{a}$ & $99.3 \mathrm{a}$ & $46.2 \mathrm{a}$ & $23.8 \mathrm{a}$ \\
\hline & $30 \% \mathrm{CO}_{2}$ & $42.7 \mathrm{a}$ & $57.8 \mathrm{a}$ & $13.2 \mathrm{a}$ & $85.3 \mathrm{a}$ & $73.6 \mathrm{a}$ & $99.6 \mathrm{a}$ & $44.2 \mathrm{a}$ & $23.6 \mathrm{a}$ \\
\hline \multirow{3}{*}{3 months } & Control & $38.5 \mathrm{a}$ & $61.9 \mathrm{a}$ & $17.1 \mathrm{a}$ & $64.8 \mathrm{~b}$ & $71.5 \mathrm{a}$ & $99.5 \mathrm{a}$ & $41.8 \mathrm{a}$ & $22.8 \mathrm{a}$ \\
\hline & $20 \% \mathrm{CO}_{2}$ & $44.2 \mathrm{a}$ & $65.9 \mathrm{a}$ & $15.4 \mathrm{a}$ & $64.8 \mathrm{~b}$ & $71.8 \mathrm{a}$ & 100.7 a & $43.1 \mathrm{a}$ & $21.4 \mathrm{a}$ \\
\hline & $30 \% \mathrm{CO}_{2}$ & $45.5 \mathrm{a}$ & 71.9 a & $16.1 \mathrm{a}$ & $78.0 \mathrm{a}$ & $72.8 \mathrm{a}$ & 99.7 a & $43.8 \mathrm{a}$ & $24.5 \mathrm{a}$ \\
\hline \multicolumn{10}{|c|}{ "Druid" Variety } \\
\hline & & $\begin{array}{c}L^{*} \\
\text { Peel }\end{array}$ & $\begin{array}{l}\text { Hue } \\
\text { Peel }\end{array}$ & $\begin{array}{c}\text { Chroma } \\
\text { Peel }\end{array}$ & $\begin{array}{l}\text { Hardness } \\
\circ \text { Durofel }\end{array}$ & $\begin{array}{c}\mathrm{L}^{*} \\
\text { Pulp }\end{array}$ & $\begin{array}{l}\text { Hue } \\
\text { Pulp }\end{array}$ & Chroma & Dry Matter \\
\hline \multirow{3}{*}{$\begin{array}{c}\text { After } \\
\text { treated }\end{array}$} & Control & $52.6 * a$ & $57.51 \mathrm{a}$ & $26.4 \mathrm{a}$ & $84.6 \mathrm{a}$ & $70.4 \mathrm{a}$ & $102.4 \mathrm{a}$ & $16.0 \mathrm{a}$ & $26.3 a$ \\
\hline & $20 \% \mathrm{CO}_{2}$ & $51.2 \mathrm{a}$ & $63.2 \mathrm{a}$ & $24.4 \mathrm{a}$ & $84.7 \mathrm{a}$ & $69.5 \mathrm{a}$ & $102.5 \mathrm{a}$ & $16.9 \mathrm{a}$ & $24.9 \mathrm{a}$ \\
\hline & $30 \% \mathrm{CO}_{2}$ & $50.3 \mathrm{a}$ & 59.7 a & $23.9 \mathrm{a}$ & $84.9 \mathrm{a}$ & $69.1 \mathrm{a}$ & $102.5 \mathrm{a}$ & $17.3 \mathrm{a}$ & $24.7 \mathrm{a}$ \\
\hline \multirow{3}{*}{1 month } & Control & $48.3 \mathrm{a}$ & $54.8 \mathrm{a}$ & $28.8 \mathrm{a}$ & $83.1 \mathrm{a}$ & $72.0 \mathrm{a}$ & $103.3 \mathrm{a}$ & $16.8 \mathrm{a}$ & $22.2 \mathrm{a}$ \\
\hline & $20 \% \mathrm{CO}_{2}$ & $49.6 \mathrm{a}$ & $59.6 \mathrm{a}$ & $26.3 \mathrm{a}$ & $82.1 \mathrm{a}$ & $72.8 \mathrm{a}$ & 102.9 a & $15.6 \mathrm{a}$ & $20.8 \mathrm{a}$ \\
\hline & $30 \% \mathrm{CO}_{2}$ & $50.9 \mathrm{a}$ & $60.7 \mathrm{a}$ & $26.2 \mathrm{a}$ & $87.4 \mathrm{a}$ & $74.3 \mathrm{a}$ & $103.2 \mathrm{a}$ & $16.8 \mathrm{a}$ & $22.9 \mathrm{a}$ \\
\hline \multirow{3}{*}{2 months } & Control & $49.9 \mathrm{a}$ & $57.1 \mathrm{a}$ & $27.2 \mathrm{a}$ & $83.2 \mathrm{a}$ & $72.2 \mathrm{a}$ & $103.5 \mathrm{a}$ & $15.8 \mathrm{a}$ & $24.7 \mathrm{a}$ \\
\hline & $20 \% \mathrm{CO}_{2}$ & $47.1 \mathrm{a}$ & $58.8 \mathrm{a}$ & $26.8 \mathrm{a}$ & $82.0 \mathrm{a}$ & $73.6 \mathrm{a}$ & $103.5 \mathrm{a}$ & $16.5 \mathrm{a}$ & $23.3 \mathrm{a}$ \\
\hline & $30 \% \mathrm{CO}_{2}$ & $45.0 \mathrm{a}$ & $59.7 \mathrm{a}$ & $26.9 a$ & $84.4 \mathrm{a}$ & $72.4 \mathrm{a}$ & 102.8 a & $15.2 \mathrm{a}$ & $24.8 \mathrm{a}$ \\
\hline \multirow{3}{*}{3 months } & Control & $49.7 \mathrm{a}$ & $65.1 \mathrm{a}$ & $24.0 \mathrm{a}$ & $74.7 \mathrm{a}$ & $71.7 \mathrm{a}$ & $103.2 \mathrm{a}$ & $15.8 \mathrm{a}$ & $23.5 \mathrm{a}$ \\
\hline & $20 \% \mathrm{CO}_{2}$ & $46.2 \mathrm{a}$ & $65.8 \mathrm{a}$ & $24.9 \mathrm{a}$ & $80.2 \mathrm{a}$ & $70.9 \mathrm{a}$ & 102.7 a & $15.5 \mathrm{a}$ & $21.8 \mathrm{a}$ \\
\hline & $30 \% \mathrm{CO}_{2}$ & $46.3 \mathrm{a}$ & $68.2 \mathrm{a}$ & $24.5 \mathrm{a}$ & $80.0 \mathrm{a}$ & $69.8 \mathrm{a}$ & $103.4 \mathrm{a}$ & $15.7 \mathrm{a}$ & $20.0 \mathrm{a}$ \\
\hline
\end{tabular}

${ }^{*}$ Mean followed by different letter in the same column are significantly different $(p \leq 0.05)$ according to ANOVA test followed by post-hoc LSD test. Potatoes $(n=10)$ were used for each treatment and storage time. 
"Negra Yema de Huevo" had significantly $(p \leq 0.05)$ darker peel (Chroma $12.67 \pm 1.27)$ and yellower pulp ( $b^{*}$ pulp $43.96 \pm 1.02$ ) than "Druid" (Chroma peel $24.12 \pm 0.31$; $b^{*}$ pulp $15.99 \pm 0.80)$. The postharvest behaviour after treatments during 3 storage months at $9 \pm 2{ }^{\circ} \mathrm{C}$ and $60 \% \mathrm{HR}$ is presented in Table 2 . As explained before the potatoes were not treated with anti-germinative products.

None of the treatments altered the peel or pulp colour nor the dry matter content in "Negra Yema de Huevo" variety during storage. After 2 and 3 months of storage, tubers treated with $30 \% \mathrm{CO}_{2}$ were harder than those treated with $20 \% \mathrm{CO}_{2}$ or the controls. This fact is interesting because the loss of texture is one of the postharvest parameters that shorten commercial life.

No statistical differences occurred in the postharvest parameters measured in "Druid" tubers variety between treatments neither after treatment nor after 1, 2, or 3 months of storage (Table 2).

During storage, tubers sprout when there is no anti-germinative, and the dormancy depends principally on the variety, storage temperature, and relative humidity used in the warehouses.

In our study "Negra Yema de Huevo" tubers (treated or not with the controlled atmospheres) began to sprout with no differences in the number (4 per potato), weight of each sprout $(0.4 \mathrm{~g})$, and the length $(2 \mathrm{~cm})$, after being stored for 2 months. After 3 months of storage, the tubers had 4 sprouts of $1.6 \mathrm{~g}$ weight, but those treated with $30 \% \mathrm{CO}_{2}$ were shorter $(4.8 \pm 1.7 \mathrm{~cm})$ than those treated with $20 \% \mathrm{CO}_{2}(5.7 \pm 1.8 \mathrm{~cm})$ or the controls $(6.1 \pm 2.4 \mathrm{~cm})$.

"Druid" tubers did not sprout after 3 months of storage.

\subsubsection{Organoleptic Analysis}

Tasters judge the potato samples (control, 20 and $30 \% \mathrm{CO}_{2}$ controlled atmosphere treatments) after the treatment and 1 month of storage. They were not able to distinguish the treated potatoes from the untreated ones neither by their external appearance nor by their olfactory-gustatory characteristics (data not shown).

\subsubsection{Germination Capacity and Productivity}

The number of tubers was not significantly different in potatoes "Negra Yema de Huevo" treated under a carbon dioxide-controlled atmosphere or not (Table 3). Moreover, the weight of control potatoes was significantly lower than that of the treated ones. Nevertheless, although the weight of "Druid" tubers was around $145 \mathrm{~g}$ in all treatments, the number of tubers was lower in those treated with $30 \% \mathrm{CO}_{2}$. None of the tubers presented physiological or pathogenic disorders after being treated.

Table 3. Effects of 10-day treatment with $30 \% \mathrm{CO}_{2}, 20 \% \mathrm{O}_{2}$, and $50 \% \mathrm{~N}_{2}$ controlled atmosphere on the germination capacity (number of tubers per plant and average potato weight).

\begin{tabular}{ccccc}
\hline & \multicolumn{2}{c}{ "Negra Yema de Huevo" } & \multicolumn{2}{c}{ “Druid" } \\
\cline { 2 - 5 } & Number of Tubers & Weight (kg) & Number of Tubers & Weight (kg) \\
\hline Control & $6.9 \pm 2.0 *$, a & $0.16 \pm 0.1 \mathrm{~b}$ & $4.7 \pm 2.4 \mathrm{a}$ & $0.14 \pm 0.1 \mathrm{a}$ \\
$20 \% \mathrm{CO}_{2}$ & $8.0 \pm 2.9 \mathrm{a}$ & $0.22 \pm 0.1 \mathrm{a}$ & $3.9 \pm 1.7 \mathrm{a}$ & $0.15 \pm 0.1 \mathrm{a}$ \\
$30 \% \mathrm{CO}_{2}$ & $7.4 \pm 1.5 \mathrm{a}$ & $0.19 \pm 0.1 \mathrm{a}$ & $2.8 \pm 1.5 \mathrm{~b}$ & $0.15 \pm 0.1 \mathrm{a}$ \\
\hline
\end{tabular}

Kruskal-Wallis test followed by comparison tests. Thirty pots were planted for each treatment and variety.

From the results, we can assert that the use of these controlled atmospheres enriched in carbon dioxide does not affect the seeds' sprout capacity and slightly enhances the yield of the Ancient potatoes "Negra Yema de Huevo". This fact is of great importance since planting seeds without the presence of the moth will reduce the inoculum that is currently being taken to the field which causes losses and spread of the quarantine moth. In addition, 
it is a way to preserve the biodiversity since farmers are leaving potato crops because they often do not find non-infested seeds, so their losses can reach more than $50 \%$ at harvest.

\subsection{Semi-Commercial Scale Trials}

Two semi-commercial trials were conducted in order to evaluate the effectiveness of the controlled atmosphere $\left(30 \% \mathrm{CO}_{2}, 20 \% \mathrm{O}_{2}\right.$, and $\left.50 \% \mathrm{~N}_{2}\right)$ in the control of T. solanivora. The pallet, containing boxes with the potatoes inoculated with the moth in its different developmental stages as well as those classified by the farmer as healthy or infested, was introduced in the controlled atmosphere chamber. The control sample was maintained in the same conditions but in the absence of carbon dioxide. After the treatment samples were evaluated for 8 weeks and the insect survivors counted.

It should be noted the effectiveness of the controlled atmosphere enriched in carbon dioxide causing 100\% death in all developmental stages of T. solanivora in both inoculated potatoes in the laboratory and those classified by the farmer (Table 4). Moreover, the infestation in the control was higher in those potatoes classified as healthy by the farmer probably because the eggs and the first instar larvae are very small and go unnoticed in the classification of potatoes. Therefore, being T. solanivora a warehouse pest, it is essential to apply an effective treatment before being stowed to avoid economic losses derived from the development of the insect during the conservation and marketing of the product.

Table 4. Effects of 10 day treatment with $30 \% \mathrm{CO}_{2}, 20 \% \mathrm{O}_{2}$, and $50 \% \mathrm{~N}_{2}$ controlled atmosphere at $17{ }^{\circ} \mathrm{C}$ on survival of Tecia solanivora at different life stages in semi-commercial trials.

\begin{tabular}{|c|c|c|c|c|}
\hline \multirow[b]{2}{*}{$\begin{array}{l}\text { SEMI-COMMERCIAL } \\
\text { TRIAL } 1\end{array}$} & \multicolumn{2}{|c|}{ Control } & \multicolumn{2}{|c|}{$30 \%$ Carbon Dioxide } \\
\hline & $\begin{array}{c}\text { Number of Insects at } \\
\text { the Beginning of the } \\
\text { Trial }\end{array}$ & $\begin{array}{l}\text { Number of Insects } \\
\text { Alive at the End of the } \\
\text { Evaluation }\end{array}$ & $\begin{array}{c}\text { Number of Insects at } \\
\text { the Beginning of the } \\
\text { Trial }\end{array}$ & $\begin{array}{l}\text { Number of Insects } \\
\text { Alive at the End of the } \\
\text { Evaluation }\end{array}$ \\
\hline Eggs & 500 & 224 & 500 & 0 \\
\hline Larvae & 500 & 227 & 500 & 0 \\
\hline Pupae & 250 & 239 & 250 & 0 \\
\hline Adults & 50 & 41 & 50 & 0 \\
\hline Infested potatoes & - & 6 & - & 0 \\
\hline \multirow[t]{2}{*}{ Healthy potatoes } & - & 18 & - & 0 \\
\hline & \multicolumn{2}{|c|}{ Control } & \multicolumn{2}{|c|}{$30 \%$ Carbon Dioxide } \\
\hline $\begin{array}{l}\text { SEMI-COMMERCIAL } \\
\text { TRIAL } 2\end{array}$ & $\begin{array}{c}\text { Number of Insects at } \\
\text { the Beginning of the } \\
\text { Trial }\end{array}$ & $\begin{array}{l}\text { Number of Insects } \\
\text { Alive at the End of the } \\
\text { Evaluation }\end{array}$ & $\begin{array}{c}\text { Number of Insects at } \\
\text { the Beginning of the } \\
\text { Trial }\end{array}$ & $\begin{array}{l}\text { Number of Insects } \\
\text { Alive at the End of the } \\
\text { Evaluation }\end{array}$ \\
\hline Eggs & 500 & 98 & 500 & 0 \\
\hline Larvae & 500 & 235 & 500 & 0 \\
\hline Pupae & 250 & 83 & 250 & 0 \\
\hline Adults & 50 & 50 & 50 & 0 \\
\hline Infested potatoes & - & 8 & - & 0 \\
\hline Healthy potatoes & - & 15 & - & 0 \\
\hline
\end{tabular}

- The number of insects in the potatoes classified as infested or healthy by the farmer is unknown at the beginning of the semicommercial trials.

The applied treatment had a gas cost of 0.48 euros $/ \mathrm{kg}$ because only one pallet with $384 \mathrm{~kg}$ was introduced in the treatment chamber, leaving a lot of empty space. If the 8 pallets that fit in the chamber were treated, the cost would be reduced to 0.06 euros $/ \mathrm{kg}$. Moreover, we estimate that 8 pallets will occupy approximately the $75 \%$ of the chamber volume, and the gas that should be injected would be much lower, estimating a finally cost of 0.015 euros $/ \mathrm{kg}$.

\subsection{Commercial Scale Trials}

Two commercial trials were performed using inoculated potato with the insect in all its developmental stages and those classified by the farmer as healthy or infested. 
Twelve pallets were treated in a controlled atmosphere automatized chamber provided with temperature, relative humidity, gases concentration control, and registration. In the first trial, the boxes were located in the 4th line from the 8th of the pallet, and $4608 \mathrm{~kg}$ of ancient potatoes were treated. In the second one, they were located in the 6th row up to the 11th of the pallet, and $7920 \mathrm{~kg}$ of potatoes were treated. Table 5 shows the efficacy of the controlled atmosphere treatment against the pest.

Table 5. Effects of 10-day treatment with $30 \% \mathrm{CO}_{2}, 20 \% \mathrm{O}_{2}$, and $50 \% \mathrm{~N}_{2}$ controlled atmosphere at $17^{\circ} \mathrm{C}$ on survival of Tecia solanivora at different life stages in commercial trials.

\begin{tabular}{|c|c|c|c|c|}
\hline \multirow[b]{2}{*}{$\begin{array}{l}\text { COMMERCIAL } \\
\text { TRIAL } 1\end{array}$} & \multicolumn{2}{|c|}{ Control } & \multicolumn{2}{|c|}{$30 \%$ Carbon Dioxide } \\
\hline & $\begin{array}{l}\text { Number of Insects at the } \\
\text { Beginning of the Trial }\end{array}$ & $\begin{array}{l}\text { Number of Insects } \\
\text { Alive at the End of the } \\
\text { Evaluation }\end{array}$ & $\begin{array}{l}\text { Number of Insects at the } \\
\text { Beginning of the Trial }\end{array}$ & $\begin{array}{l}\text { Number of Insects } \\
\text { Alive at the End of the } \\
\text { Evaluation }\end{array}$ \\
\hline Eggss & 450 & 261 & 2700 & 0 \\
\hline Larvae & 450 & 279 & 2700 & 0 \\
\hline Pupae & 45 & 28 & 180 & 0 \\
\hline Adults & 45 & 45 & 180 & 0 \\
\hline Infested potatoes & - & 6 & - & 0 \\
\hline \multirow[t]{2}{*}{ Healthy potatoes } & - & 2 & - & 0 \\
\hline & \multicolumn{2}{|c|}{ Control } & \multicolumn{2}{|c|}{$30 \%$ Carbon Dioxide } \\
\hline $\begin{array}{l}\text { COMMERCIAL } \\
\text { TRIAL } 2\end{array}$ & $\begin{array}{l}\text { Number of Insects at the } \\
\text { Beginning of the Trial }\end{array}$ & $\begin{array}{l}\text { Number of Insects } \\
\text { Alive at the End of the } \\
\text { Evaluation }\end{array}$ & $\begin{array}{l}\text { Number of Insects at the } \\
\text { Beginning of the Trial }\end{array}$ & $\begin{array}{c}\text { Number of Insects } \\
\text { Alive at the End of the } \\
\text { Evaluation }\end{array}$ \\
\hline Eggs & 450 & 399 & 1800 & 0 \\
\hline Larvae & 450 & 441 & 1800 & 0 \\
\hline Pupae & 45 & 39 & 180 & 0 \\
\hline Adults & 45 & 45 & 180 & 0 \\
\hline Infested potatoes & - & 0 & - & 0 \\
\hline Healthy potatoes & - & 0 & - & 0 \\
\hline
\end{tabular}

- The number of insects in the potatoes classified as infested or healthy by the farmer is unknown at the beginning of the commercial trials.

Figure 4 shows external and dissection views of infested potatoes at different infestation stages. At the early stage or low infestation level, potatoes appeared healthy even though they were infested internally by neonates. As neonate larvae developed over time, or at higher infestation intensities, potatoes showed increased exit holes of mature larvae on external surfaces as they left to pupate and intensified stain and larger larvae on dissection surfaces and, thereby, became unacceptable commercially.

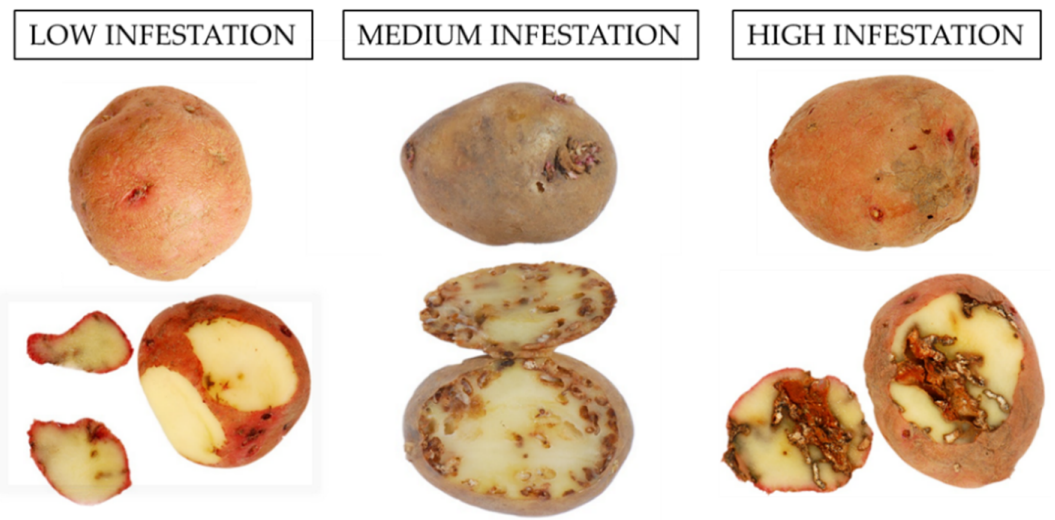

Figure 4. External and dissection views of infested control potatoes with Tecia solanivora. Low infestation (tubers classified by the farmer) and medium and high infestation (tubers infested in the laboratory). Photos: M.G. Lobo and F. Correa. 


\section{Discussion}

Methyl bromide has been widely used as a fumigant in agriculture, warehousing, and quarantine treatments. It has a wide spectrum of activity, and its application is very easy. Nevertheless, its use is being phased out and, in many countries, can only be used as a fumigant for quarantine and pre-shipment purposes since it acts as a catalyst for the reaction that destroys ozone and is a product with a difficult degradation, being accumulated on usable organs of cultivated plants, which constitutes a danger to human health. The development of non-chemical quarantine treatments to meet export requirements has become increasingly necessary but is determined by the commodity tolerance.

In order to achieve a postharvest treatment that can be used as a quarantine treatment against $T$. solanivora, it is necessary to know how susceptible the developmental stages of the insect are. Thus, the eggs needed 10 days of exposure at $30 \% \mathrm{CO}_{2}, 20 \% \mathrm{O}_{2}$, and $50 \% \mathrm{~N}_{2}$ to ensure that none of them were viable ( $100 \%$ effectivity). The pupae required at least $30 \% \mathrm{CO}_{2}$ exposure for at least 7 days while adults were very susceptible, and an exposure to $10 \% \mathrm{CO}_{2}$ for 4 days was more than enough to achieve $100 \%$ mortality. The larvae required a 10-day treatment in a controlled atmosphere with at least $20 \%$ $\mathrm{CO}_{2}$. In general, high $\mathrm{CO}_{2}$ appear to induce metabolic arrest or a reduced metabolic rate, resulting in low ATP levels, loss of membrane function, and eventual cell death [30]. Riudavets et al. [31] observed that the exposure of Tuta absoluta to a modified atmosphere of $95 \% \mathrm{CO}_{2}$ at $25^{\circ} \mathrm{C}$ for $48 \mathrm{~h}$ was effective for the control of all its developmental stages. Nevertheless, an increase in the exposure time to $72 \mathrm{~h}$ was necessary to obtain the same level of control at $40 \% \mathrm{CO}_{2}$. Bumroongsook and Kilaso [32] considered the use of a $100 \% \mathrm{CO}_{2}$ controlled atmosphere to achieve $100 \%$ mortality of both adults and larvae of Frankliniella schultzei a common quarantine blossom thrip on cut lotus flowers. The combination of treatments can have synergistic effects. Thus, for those products that are not affected by high temperatures, the exposure to a controlled $\mathrm{CO}_{2}$ atmosphere can be diminished when performed over $30^{\circ} \mathrm{C}$ [33]. Moreover, Grout et al. [34] shorten the cold disinfestation treatment for Thaumatotibia leucotreta in citrus fruit by its combination with carbon dioxide fumigation. Alonso et al. [35] observed that a $95 \% \mathrm{CO}_{2}$ atmosphere at $20{ }^{\circ} \mathrm{C}$ for $20 \mathrm{~h}$ before the standard cold quarantine treatment reduced the lethal times for Ceratitis capitata Wiedemann in "Fortune" mandarins. Ruidavets et al. (2014) [36] pointed out that the addition of sulphur dioxide $\left(\mathrm{SO}_{2}\right)$ to a high $\mathrm{CO}_{2}$ modified atmosphere shorten the treatment length necessary to achieve the control of Sitophilus oryzae and Triboulium confusum.

The commodity quality has to be preserved after the quarantine treatment and storage. The treatment should not diminish the self-life or adversely affect the sensorial quality of the product. At this point, potatoes treated with $30 \% \mathrm{CO}_{2}, 20 \% \mathrm{O}_{2}$, and $50 \% \mathrm{~N}_{2}$ for 10 days did not behave differently than the control in terms of quality, postharvest life, and organoleptic analysis. Zhang et al. [37] found an increase in the health promoting compounds and the organoleptic properties in tomato fruits stored under dioxide carbon enriched atmosphere. Potato producers increase the storability (more than 6 months) using refrigeration combined with a high carbon dioxide controlled atmosphere and in the absence of ethylene because its affect potato fry colour and increase reducing sugars content [38,39]. Golding et al. [40] and Kumar et al. [41] showed the potential of using high $\mathrm{CO}_{2}$ combination treatments with cold storage on Navel oranges without affecting its quality after treatment and storage. Palou et al. [42] achieve a complete insect (Mediterranean fruit fly) mortality with no negative effects on "Clemenules" mandarins when exposed 3 days at $1.5^{\circ} \mathrm{C}$ followed by $20 \mathrm{~h}$ to a controlled atmosphere of $95 \% \mathrm{CO}_{2}$ at $25^{\circ} \mathrm{C}$. Alonso et al. [35] observed that the quarantine treatment in "Fortune" mandarins resulted in an increased levels of fruit volatiles (ethanol and acetaldehyde) but without a detrimental effect on ether fruit external appearance nor the organoleptic characteristics of the fruit. In general, since the effects of insecticidal treatments on treated commodities can considerably differ depending on species and cultivar, varietal testing is essential to establish the tolerance of fruits and vegetables to different quarantine treatments [43]. In the case of insecticidal CA, 
the optimum combination of atmosphere gas composition, temperature, and length of application should be pursued for each pest-host system.

Seed quality is dependent on freedom from pests and diseases, defects, tuber vigour, and a physiological age appropriate for the local growing season and end use. For that reason, when a quarantine treatment is needed, it should not affect the capability of the potato seed to sprout. The tuber number and weight are the main components of yield. The number of tubers per plant is highly dependent on genotype and environment; thus, agronomic management as sowing date (that modulates the inductive conditions of temperature and photoperiod), plant density, hilling, fertilisation, and water availability, amongst others, are key to avoid limitations during critical period, identified around tuberization $[44,45]$. Another attractive and interesting result of this treatment is that it can be used to kill the Guatemalan potato moth in the potatoes seeds without affecting the number, size, and weight of the sprouts. Gong et al. [46] evaluated the impact of some carbon dioxide controlled atmosphere treatments against two-spotted spider mite (TSSM), Tetranychus urticae, on the seedling of five host plants (cucumber, eggplant, rape, green peppers, and strawberries). The effective controlled atmosphere of $\mathrm{CO}_{2}$ could kill the TSSM, but only strawberries were not affected by the treatments.

In this study, we conducted two semi-commercial trials and two commercial trials. The two types of trials differed in scale and level of automatic control. These trials assured that the treatment proposed as a quarantine postharvest treatment against the Guatemalan potato moth (Tecia solanivora Povolny) is effective. Moreover, the facilities to perform it are rather simple, and the costs not very high. In the future, to shorten the commercial treatment will be necessary to combine the treatment with low or high temperatures or positive pressure.

\section{Conclusions}

The application of an atmosphere enriched in carbon dioxide, as a possible postharvest quarantine treatment against T. solanivora (Guatemalan potato moth), is effective and economically viable by causing 100\% mortality of the insect in all its developmental stages, as it does not affect the physicochemical and organoleptic potato quality nor its commercial life. In addition, it can be applied to seed potatoes to reduce the inoculum that would go to the field, reducing its spread because it does not affect the germination capacity nor the production and size of the potato. The trials were performed both at semi-commercial and commercial scale, and the treatment that ensured quarantine consisted of a controlled atmosphere of $30 \pm 2 \%$ carbon dioxide, $20 \pm 2 \%$ oxygen, and $50 \pm 2 \%$ nitrogen for 10 days under a temperature of $18 \pm 2{ }^{\circ} \mathrm{C}$. The results hold promise for the development of a commercial treatment to meet quarantine restrictions against $T$. solanivora pest in potato.

Author Contributions: M.G.L.: conceptualization, formal analysis, investigation, methodology, supervision, roles/writing — original draft, review and editing, visualization, project administration, and funding acquisition. C.G.-G.: formal analysis, investigation, methodology, review and editing. D.R.: methodology and visualization. R.C.: methodology and review and editing. All authors have read and agreed to the published version of the manuscript.

Funding: This research was funded by Instituto Nacional de Investigación y Tecnología Agraria y Alimentaria (RTA2011-00125-00-00).

Informed Consent Statement: Informed consent was obtained from all subjects involved as tasters in the organoleptic study.

Acknowledgments: The authors would like to acknowledge M. Eugenia Trujillo, Santiago Perera, Antonio Bentabol, and Pedro Marrero for their technical support.

Conflicts of Interest: The authors declare no conflict of interest. The funders had no role in the design of the study; in the collection, analyses, or interpretation of data; in the writing of the manuscript; or in the decision to publish the results. 


\section{References}

1. Povolný, D. Scrobipalpopsis Solvanivora Sp.n.-A New Pest of Potato (Solanum Tuberosum) from Central America. Available online: https: / / www.cabi.org/isc/abstract/19740513471 (accessed on 4 August 2021).

2. EPPO Global Database. Available online: https://gd.eppo.int/reporting/article-2954 (accessed on 9 July 2021).

3. Villanueva-Mejía, D.; Saldamando-Benjumea, C. Tecia Solanivora, Povolny (Lepidoptera: Gelechiidae): Una Revisión Sobre Su Origen, Dispersión y Estrategias de Control Biológico. Ing. Cienc. 2013, 9, 197-214. [CrossRef]

4. EPPO Global Database. Available online: https://gd.eppo.int/reporting/article-5149 (accessed on 9 July 2021).

5. EPPO Global Database. Available online: https://gd.eppo.int/reporting/article-5876 (accessed on 9 July 2021).

6. EPPO Global Database. Available online: https://gd.eppo.int/reporting/article-6048 (accessed on 9 July 2021).

7. OEPP/EPPO Daata Sheets on Quarantine Pests: Tecia solanivora. OEPP Bull. 2006, 36, 175-178. [CrossRef]

8. Karlsson, M.; Proffit, M.; Birgersson, G. Host-Plant Location by the Guatemalan Potato Moth Tecia Solanivora Is Assisted by Floral Volatiles. Chemoecology 2017, 27, 1-12. [CrossRef] [PubMed]

9. Bosa, C.F.; Cotes, A.M.; Fukumoto, T.; Bengtsson, M.; Witzgall, P. Pheromone-Mediated Communication Disruption in Guatemalan Potato Moth, Tecia solanivora. Entomol. Exp. Appl. 2005, 114, 137-142. [CrossRef]

10. Ríos, D.; Ghislain, M.; Rodriguez, F.; Spooner, D. What Is the Origin of the European Potato? Evidence from Canary Island Landraces. Crop Sci. 2007, 47. [CrossRef]

11. Ruiz de Galarreta Gómez, J.I.; Ríos Mesa, D.; Instituto Vasco de Investigación y Desarrollo Agrario. Variedades de Patata y Papas Españolas; NEIKER: Instituto Vasco de Investigación y Desarrollo Agrario: País Vasco, Spain, 2008; ISBN 978-84-612-3401-1.

12. Ríos, D. Caracterización Morfológica y Ecofisiológica de un Grupo de Cultivares Locales de Papas de Tenerife. Universidade de Santiago de Compostela. 2002. Available online: http:/ / purl.org/dc/dcmitype/Text (accessed on 9 July 2021).

13. de Lara, D.R.M.; Corral, S.; de la Nuez, D.L.; Hernández, J.H. A Socio-Institutional Approach to Brighten Complexity under Agricultural Pest Invasion Conditions. Sustainbility 2016, 8, 598. [CrossRef]

14. Ramírez, J.; Gomez, M.I.; Cotes Torres, J.M.; Nústez, C. Insecticidal Effect of Labiate Essential Oils on Tecia Solanivora Povolny in Laboratory. Agron. Colomb. 2010, 28, 255-263.

15. Fernández, S. Efecto de dos prácticas culturales sobre poblaciones de insectos plagas de tubérculos del cultivo de papa (Solanum tuberosum L.). Rev. Fac. Agron. Univ. Zulia 1997, 14, 603-610. Available online: https://produccioncientificaluz.org/index.php/ agronomia/article/view/26160/26785 (accessed on 9 July 2021).

16. Zepeda, J.F.; Barreto-Triana, N.; Baquero-Haeberlin, I.; Espitia-Malagón, E.; Fierro-Guzmán, H.; López, N. An Exploration of the Potential Benefits of Integrated Pest Management Systems and the Use of Insect Resistant Potatoes to Control the Guatemalan Tuber Moth (Tecia Solanivora Povolny) in Ventaquemada, Colombia; International Food Policy Research Institute: Washington, DC, USA, 2006.

17. Santa, J.D.; Berdugo-Cely, J.; Cely-Pardo, L.; Soto-Suárez, M.; Mosquera, T.; Galenao, C.H. QTL Analysis Reveals Quantitative Resistant Loci for Phytophthora Infestans and Tecia Solanivora in Tetraploid Potato (Solanum Tuberosum L.). PLoS ONE 2018, 13, e0199716. [CrossRef] [PubMed]

18. Tang, J.; Ikediala, J.N.; Wang, S.; Hansen, J.D.; Cavalieri, R.P. High-Temperature-Short-Time Thermal Quarantine Methods. Postharvest Biol. Technol. 2000, 21, 129-145. [CrossRef]

19. Fields, P.; White, N. Alternatives to Methyl Bromide Treatments for Stored-Product and Quarantine Insects. Annu. Rev. Entomol. 2002. [CrossRef] [PubMed]

20. Follett, P. Irradiation as a Methyl Bromide Alternative for Postharvest Control of Omphisa Anastomosalis (Lepidoptera: Pyralidae) and Euscepes Postfasciatus and Cylas Formicarius Elegantulus (Coleoptera: Curculionidae) in Sweet Potatoes. J. Econ. Entomol. 2006, 99, 32-37. [CrossRef]

21. Tang, J.; Mitcham, E.; Wang, S.; Lurie, S. (Eds.) Heat Treatments for Postharvest Pest Control: Theory and Practice; CABI: Wallingford, UK, 2007; p. 349.

22. Das, I.; Kumar, G.; Shah, N.G. Microwave Heating as an Alternative Quarantine Method for Disinfestation of Stored Food Grains. Int. J. Food Sci. 2013, 2013, 926468. [CrossRef] [PubMed]

23. Nicolas, G.; Sillans, D. Immediate and Latent Effects of Carbon Dioxide on Insects. Annu. Rev. Entomol. 1989, 34, 97-116. [CrossRef]

24. Riudavets, J.; Castañé, C.; Alomar, O.; Pons, M.J.; Gabarra, R. The Use of Carbon Dioxide at High Pressure to Control Nine Stored-Product Pests. J. Stored Prod. Res. 2010, 46, 228-233. [CrossRef]

25. Navarro, S.; Timlick, B.; Demianyk, C.J.; White, N.D.G. Chapter 16-Controlled or Modified Atmospheres. In Stored Products Protection; Hagstrum, D.W., Phillips, T.W., Cuperus, G., Eds.; Kansas State University: Manhattan, KS, USA, 2012; pp. 191-202, ISBN 978-0-9855003-0-6.

26. Fukuda, S.; Yasunaga, E.; Nagle, M.; Yuge, K.; Sardsud, V.; Spreer, W.; Müller, J. Modelling the Relationship between Peel Colour and the Quality of Fresh Mango Fruit Using Random Forests. J. Food Eng. 2014, 131, 7-17. [CrossRef]

27. Ibarra-Garza, I.P.; Ramos-Parra, P.A.; Hernández-Brenes, C.; Jacobo-Velázquez, D.A. Effects of Postharvest Ripening on the Nutraceutical and Physicochemical Properties of Mango (Mangifera Indica L. Cv Keitt). Postharvest Biol. Technol. 2015, 103, 45-54. [CrossRef]

28. Abbott, W.S. A Method of Computing the Effectiveness of an Insecticide. J. Econ. Entomol. 1925, 18, 265-267. [CrossRef]

29. Henderson, C.F.; TILTON, E.W. Tests with Acaricides against the Brown Wheat Mite12. J. Econ. Entomol. 1955, 48, 157-161. [CrossRef] 
30. Mitcham, E.; Martin, T.; Zhou, S. The Mode of Action of Insecticidal Controlled Atmospheres. Bull. Entomol. Res. 2006, 96, 213-222. [CrossRef]

31. Riudavets, J.; Alonso, M.; Gabarra, R.; Arnó, J.; Jaques, J.A.; Palou, L. The Effects of Postharvest Carbon Dioxide and a Cold Storage Treatment on Tuta Absoluta Mortality and Tomato Fruit Quality. Postharvest Biol. Technol. 2016, 120, 213-221. [CrossRef]

32. Bumroongsook, S.; Kilaso, M. Modified Atmosphere for Thrip Disinsection on Cut Lotus Flowers. Appl. Ecol. Environ. Res. 2018, 16, 5237-5247. [CrossRef]

33. Seki, M.; Murai, T. Responses of Five Adult Thrips Species (Thysanoptera; Thripidae) to High-Carbon Dioxide Atmospheres at Different Temperatures. Appl. Entomol. Zool. 2012, 47, 125-128. [CrossRef]

34. Grout, T.G.; Stoltz, K.C. Carbon Dioxide Fumigation to Shorten Cold Disinfestation Treatments for Thaumatotibia Leucotreta (Lepidoptera: Tortricidae) in Citrus Fruit. J. Econ. Entomol. 2020, 113, 144-151. [CrossRef]

35. Alonso, M.; Del Río, M.Á.; Jacas, J.-A. Carbon Dioxide Diminishes Cold Tolerance of Third Instar Larvae of Ceratitis Capitata Wiedemann (Diptera: Tephritidae) in 'Fortune' Mandarins: Implications for Citrus Quarantine Treatments. Postharvest Biol. Technol. 2005, 36, 103-111. [CrossRef]

36. Riudavets, J.; Pons, M.J.; Gabarra, R.; Castañé, C.; Alomar, O.; Vega, L.F.; Guri, S. The Toxicity Effects of Atmospheres with High Content of Carbon Dioxide with Addition of Sulphur Dioxide on Two Stored-Product Pest Species: Sitophilus Oryzae and Tribolium Confusum. J. Stored Prod. Res. 2014, 57, 58-62. [CrossRef]

37. Zhang, Z.; Liu, L.; Zhang, M.; Zhang, Y.; Wang, Q. Effect of Carbon Dioxide Enrichment on Health-Promoting Compounds and Organoleptic Properties of Tomato Fruits Grown in Greenhouse. Food Chem. 2014, 153, 157-163. [CrossRef] [PubMed]

38. Daniels-Lake, B.; Prange, R.; Walsh, J. Carbon Dioxide and Ethylene: A Combined Influence on Potato Fry Color. Hortic. Sci. HORTSCI 2005, 40, 1824-1828. [CrossRef]

39. Daniels-Lake, B.J. Effects of Elevated $\mathrm{CO}_{2}$ and Trace Ethylene Present Throughout the Storage Season on the Processing Colour of Stored Potatoes. Potato Res. 2012, 55, 157-173. [CrossRef]

40. Golding, J.; Jessup, A.; Spohr, L.; Daniels, D.; Satyan, S.; Arakawa, C.; McGlasson, B.; Jacas, J. Short Term High CO $\mathrm{H}_{2}$ in Combination with $0{ }^{\circ} \mathrm{C}$ as Potential Disinfestation Treatment for Queensland Fruit Fly (Bactrocera Tryoni (Froggatt)). Acta Hortic. 2010, $391-394$. [CrossRef]

41. Kumar, M.; McGlasson, W.B.; Holford, P.; Golding, J. Effects of Very High Carbon Dioxide Treatment and Cold Storage on the Quality of Navel Oranges. Acta Hortic. 2016, 91-98. [CrossRef]

42. Palou, L.; Jacas, J.-A.; Marcilla, A.; Alonso, M.; del Río, M.Á. Physico-Chemical and Sensory Quality of 'Clemenules' Mandarins and Survival of the Mediterranean Fruit Fly as Affected by Complementary Cold and Carbon Dioxide Quarantine Treatments. Postharvest Biol. Technol. 2008, 48, 443-450. [CrossRef]

43. Follett, P.A.; Neven, L.G. Current Trends in Quarantine Entomology. Annu. Rev. Entomol. 2006, 51, 359-385. [CrossRef] [PubMed]

44. Rudisile, O.J.K. Determinación del Periodo Crítico en Papa; Universidad Austral de Chile: Valdivia, Chile, 2017 ; p. 38.

45. Carolina Lizana, X.; Sandaña, P.; Behn, A.; Ávila-Valdés, A.; Ramírez, D.A.; Soratto, R.P.; Campos, H. Chapter 18-Potato. In Crop Physiology Case Histories for Major Crops; Sadras, V.O., Calderini, D.F., Eds.; Academic Press: Cambridge, MA, USA, 2021; pp. 550-587, ISBN 978-0-12-819194-1.

46. Gong, Y.-J.; Cao, L.-J.; Wang, Z.-H.; Zhou, X.-Y.; Chen, J.-C.; Hoffmann, A.A.; Wei, S.-J. Efficacy of Carbon Dioxide Treatments for the Control of the Two-Spotted Spider Mite, Tetranychus Urticae, and Treatment Impact on Plant Seedlings. Exp. Appl. Acarol. 2018, 75, 143-153. [CrossRef] 